\title{
Archaeological Monitoring for San Antonio Water Systems: Henry B. Gonzalez Convention Center Expansion
}

Cynthia L. Tennis

Center for Archaeological Research

I. Waynne Cox

Center for Archaeological Research

Follow this and additional works at: https://scholarworks.sfasu.edu/ita

Part of the American Material Culture Commons, Archaeological Anthropology Commons, Environmental Studies Commons, Other American Studies Commons, Other Arts and Humanities Commons, Other History of Art, Architecture, and Archaeology Commons, and the United States History Commons

Tell us how this article helped you.

This Article is brought to you for free and open access by the Center for Regional Heritage Research at SFA ScholarWorks. It has been accepted for inclusion in Index of Texas Archaeology: Open Access Gray Literature from the Lone Star State by an authorized editor of SFA ScholarWorks. For more information, please contact cdsscholarworks@sfasu.edu. 


\section{Archaeological Monitoring for San Antonio Water Systems: Henry B. Gonzalez Convention Center Expansion}

\section{Creative Commons License}

\section{(c) (1) \&}

This work is licensed under a Creative Commons Attribution-NonCommercial 4.0 International License 
Archaeological Monitoring for

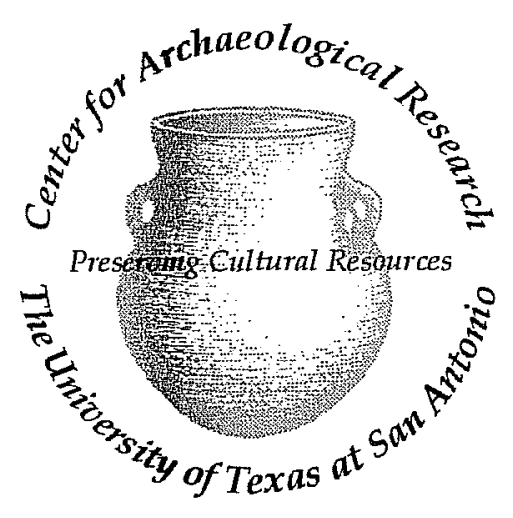
San Antonio Water Systems:

Henry B. Gonzalez Convention Center Expansion

Cynthia L. Tennis and I. Waynne Cox

Archaeological Survey Report, No. 281

Center for Archaeological Research

The University of Texas at San Antonio 


\title{
Archaeological Monitoring for San Antonio Water Systems:
}

\section{Henry B. Gonzalez Convention Center Expansion}

\author{
Cynthia L. Tennis and I. Waynne Cox
}

Robert J. Hard and C. Britt Bousman

Principal Investigators

Texas Antiquites Permit No. 1790

Ccopyright

Center for Archaeological Research

The University of Texas at San Antonio

Archaeological Survey Report, No. 281

1998 
The following information is provided in accordance with the General Rules of Practice and Procedure, Chapter 41.11 (Investigative Reports), Texas Antiquities Committee:

1. Type of investigation: Monitoring and testing

2. Project name: San Antonio Water Systems: Henry B. Gonzalez Convention Center Expansion

3. County: Bexar

4. Principal investigators: Robert J. Hard and C. Britt Bousman

5. Name and location of sponsoring agency: Fernandez, Frazer, and White, 11824 Radium, San Antonio, Texas 78216

6. Texas Antiquities Committee Permit No.: 1790

7. Published by the Center for Archaeological Research, The University of Texas at San Antonio, San Antonio, Texas 78249-0658, 1998

A list of publications offered by the Center for Archaeological Research is available. Call (210) 458-4378; write to the Center for Archaeological Research, The University of Texas at San Antonio, 6900 N. Loop 1604 W., San Antonio, Texas 78249-0658; e-mail to car@lonestar.utsa.edu; or visit CAR's Web site at http://www.csbs.utsa.edu/ research/car/index.htm. 


\begin{abstract}
In 1997 the Center for Archaeological Research (CAR) of The University of Texas at San Antonio (UTSA) conducted archaeological investigations for San Antonio Water Systems (SAWS) in conjunction with sewerand water-line installations for the Henry B. Gonzalez Convention Center Expansion Project in downtown San Antonio. Gradall trenching was used to test portions of the proposed route of a 60 -inch sanitary-sewer line being installed in connection with the construction project. Excavation for the sewer line and for an additional 8-inch water main within HemisFair Park were periodically monitored. Although three late-nineteenth- or early-twentiethcentury features were encountered, no pre-1850 deposits were impacted by this utility installation project.
\end{abstract}




\section{Contents}

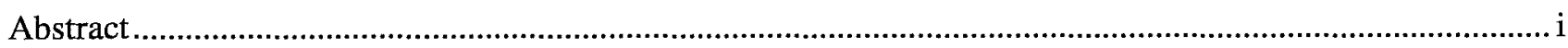

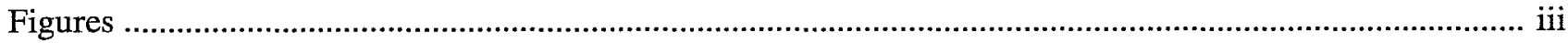

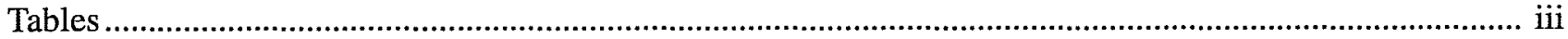

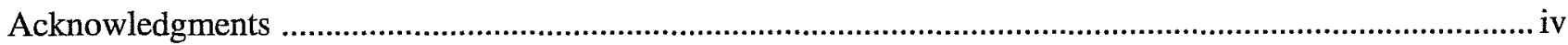

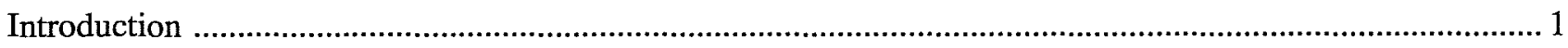

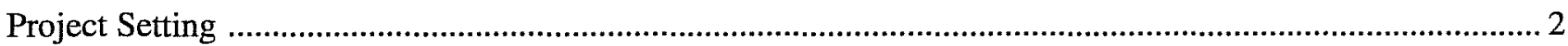

Historical Background and Previous Archaeology .................................................................................. 3

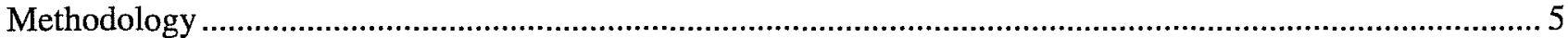

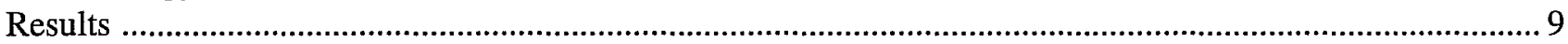

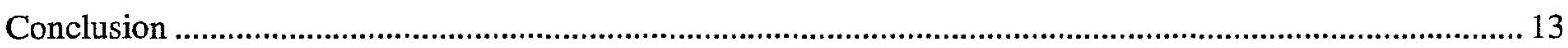

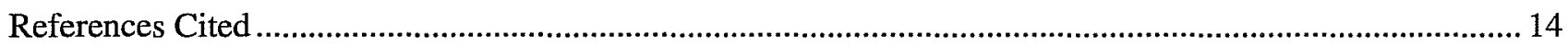

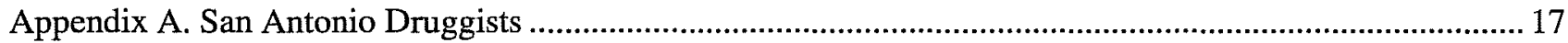




\section{Figures}

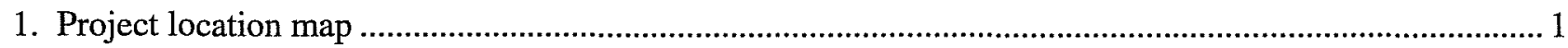

2. Profile of trench at south side of Bowie Street showing disturbed and natural stratigraphy ...................... 2

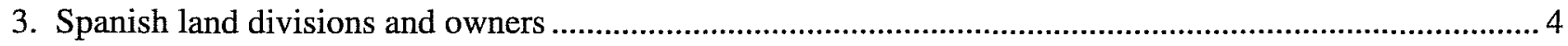

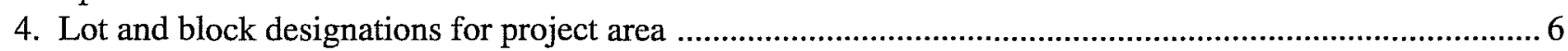

5. Details from 1873 Bird's Eye View of the City of San Antonio ............................................................... 6

6. Route of SAWS sewer and water trenches showing areas of historic and modern impact ......................... 7

7. Area of Gradall investigations in undeveloped island between Bowie and Market streets ........................ 8

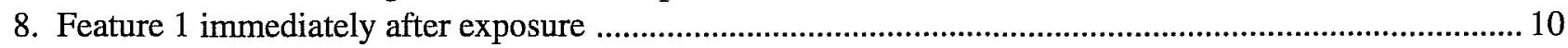

9. Feature 1 following partial cave-in and subsequent investigation .................................................. 10

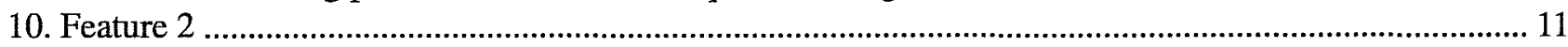

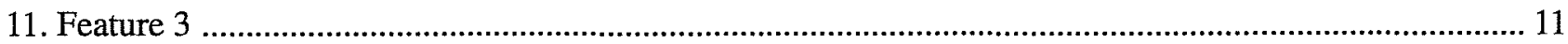

\section{Tables}

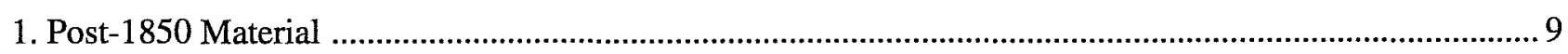

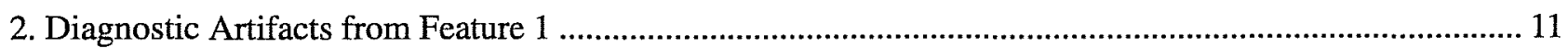

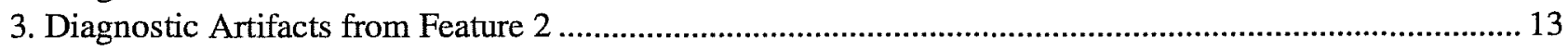

4. Diagnostic Artifacts from Feature 3 ................................................................................................... 13 


\section{Acknowledgments}

The authors wish to thank Mike Finger and Frank Schwartz of San Antonio Water Systems for their support during this project. We also want to acknowledge the crew from Ramex Construction and Gabriel Sagredo, our Gradall operator from Aaron Construction, for their cooperation and interest. Thanks also to Marcie Renner and James Rodriguez, CAR technical editors, and to Bruce Moses and Chris Butler, CAR illustrators, for their assistance with the final report. 


\section{Introduction}

During the first six months of 1997, the Center for Archaeological Research (CAR) of The University of Texas at San Antonio (UTSA) conducted archaeological investigations for San Antonio Water Systems (SAWS) in conjunction with sewer- and water-line installations for the Henry B. Gonzalez Convention Center Expansion Project in downtown San Antonio. The proposed route of the 60-inch sanitary-sewer line extends 1,000 ft from the corner of Market and Bowie streets, east across a currently undeveloped traffic island, and south through a section of HemisFair Park (Figure 1). The installation of an additional $400 \mathrm{ft}$ of 8-inch water main was planned within HemisFair Park.

Prior to initiation of this project, CAR conducted two archival and archaeological assessments of the area to be impacted by the Convention Center expansion for the city of San Antonio (Johnson and Cox 1995; Johnson et al. 1997). These reports summarize previous archaeological work in downtown San Antonio, including numerous investigations of late-nineteenth and early-twentieth-century domiciles and neighborhoods. They also highlight the fact that, with the exception of the Spanish colonial period, very few historic sites pre-dating the 1870s have been recorded in the downtown area. The authors concluded that while the 1966-1968 construction activities related to HemisFair undoubtedly destroyed many of the historic structure foundations and artifact scatters in the area, other historic deposits may have actually been protected by filling and berming during landscaping activities.

Based on this assessment, a scope of work was designed for this project in consultation with the Texas Historical Commission (THC). This three-part investigation included an archival search of ownership

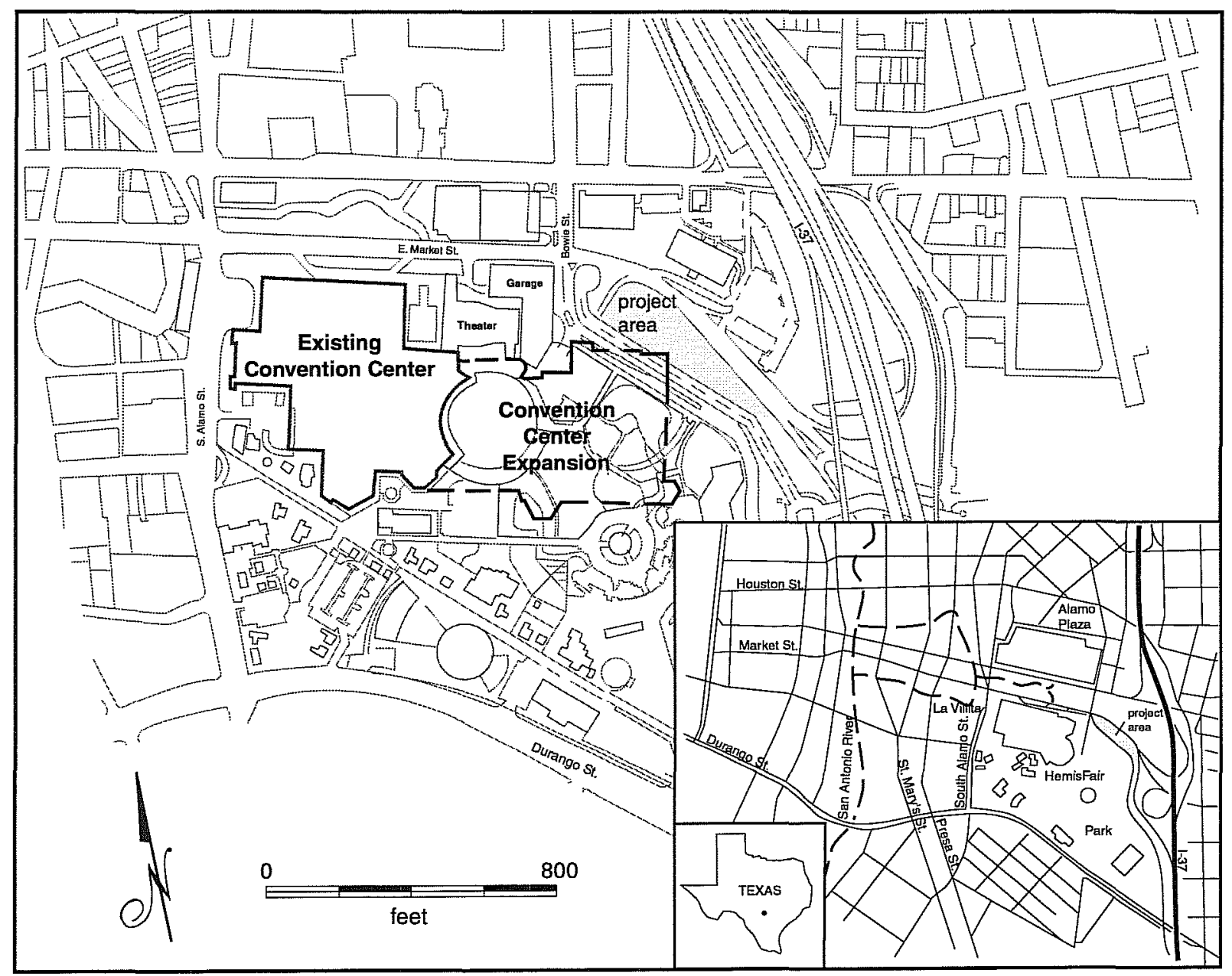

Figure 1. Project location map. 
and land-use records, excavation of a Gradall trench along a portion of the sewer-line right-of-way, and spot monitoring of the actual trenching activities.

For this project, THC defined significant archaeological deposits necessitating work stoppage for further investigation as any intact deposit predating 1850 or "unique or rare" deposits post-dating 1850. The project was conducted under Texas Antiquities Permit No. 1790 by CAR archaeological research associates I. Waynne Cox and Cynthia L. Tennis. Coprincipal investigators for the project were Robert $\mathrm{J}$. Hard and C. Britt Bousman. Field notes, archival information, and artifacts are curated at the CAR laboratory.

\section{Project Setting}

The project area is located in downtown San Antonio where the upper level soils, as described by Taylor et al. (1991), are dominated by the Houston Black series. This series consists of calcareous, dark gray to black clayey soils. The surface layer varies from 34-38 inches in thickness and has a firm, blocky structure.
The subsurface layer is from 12-20 inches thick and is gray or dark gray clay with grayish-brown or olivebrown streaks. Both of these layers crack when dry and swell when wet. These upper soils are situated on the Quaternary aged Fluviatile Terrace Deposits formation which is predominately composed of gravel, limestone, dolomite, and chert. This strata was encountered at depths 4-17 ft below the surface in geotechnical test borings drilled in the project area by ATC Associates (1996). At depths 13-24 ft below the surface, tan and gray clay representing the underlying Cretaceous aged Taylor Formation was encountered. Groundwater was encountered in eight of the 10 monitor wells drilled by ATC at depths from 12.8-23.58 $\mathrm{ft}$ below the surface (Figure 2). The climate of the area is defined as modified subtropical, with hot summers and cool winters. January has the coldest average temperatures $\left(62.3^{\circ} \mathrm{F}\right)$, while August has the highest average temperature $\left(94.2^{\circ} \mathrm{F}\right)$. Yearly rainfall averages 27.89 inches and the growing season in the southern part of Bexar County is 275 days (Taylor et al. 1991).

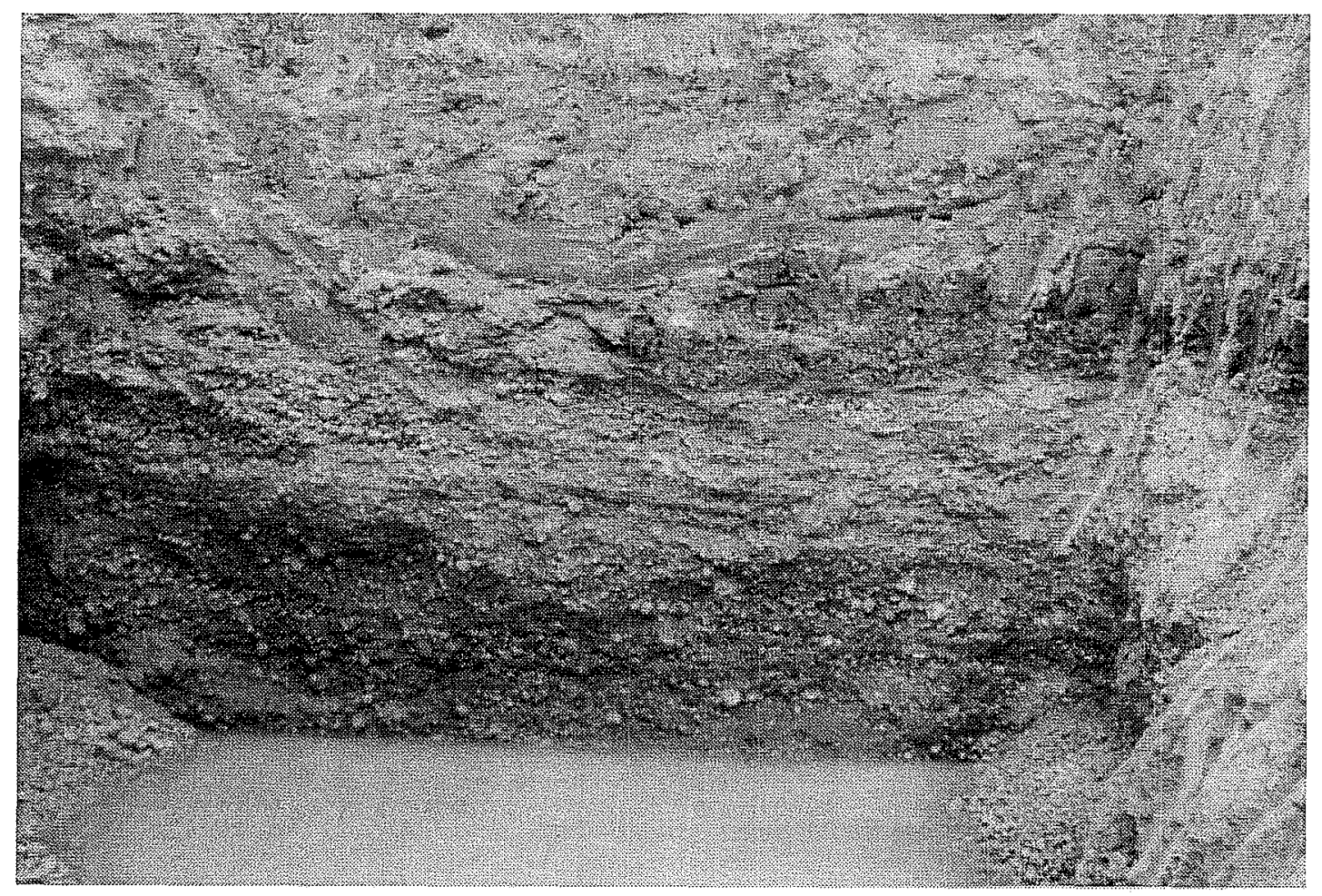

Figure 2. Profile of trench at south side of Bowie Street showing disturbed and natural stratigraphy and groundwater. Looking south. 


\section{Historical Background and Previous Archaeology}

Recently, several extensive reports have been published by CAR detailing the previous archaeology in downtown San Antonio and the archival history in and around the Henry B. Gonzalez Convention Center. Bousman et al. (1995) and Fox et al. (1997) provide in-depth information on the history of the neighborhoods just to the east of the project area. Johnson and Cox (1995), Johnson et al. (1997), and Cox and Fox (1983) focus on the immediate area. The interested reader is referred to these reports for detailed accounts of the multifaceted history of downtown San Antonio. Aside from a brief summary of the general history of the city, the background section of this report focuses on the information pertaining directly to the current SAWS project area.

\section{Prehistoric Period}

The modern metropolitan San Antonio area has been occupied by various cultural groups for more than 10,000 years. Prehistoric sites ranging in age from the Paleoindian period (9000-6000 B.C.) to the Late Prehistoric period, which ended with the arrival of the Spaniards, have been identified along the creeks and rivers in northern and southern Bexar County. However, perhaps because of the early and continuous development along the San Antonio River, our knowledge of prehistoric occupations in the center of the county is limited. With the exception of the St. Mary's Hall site (41BX229), a possible Paleoindian site excavated by a UTSA field school in 1977 (Hester 1978); 41BX1, a Middle Archaic cemetery site at Olmos Dam (Lukowski 1988); and human remains dating to the Late Prehistoric period recovered from 41BX917 in La Villita (Tennis 1994), the prehistoric past of downtown San Antonio remains unknown.

\section{Historic Period}

The Historic period in the New World generally begins with the written accounts produced by the Spaniards and other Europeans upon their arrival in this hemisphere. These early accounts tell of hundreds of small, independent Native American groups occupying the south Texas area (Campbell and Campbell 1985:1). These bands of hunters and gatherers may have represented as many as six major language groups including the Coahuiltecans. The Payaya, one of the Coahuiltecan speaking groups, are described in a 1691 eyewitness account of a native settlement along the San Antonio River within the present city limits (Campbell and Campbell 1985:7-8).

Although Spain initially recognized the Rio Grande as the northern boundary of New Spain, pressures by French explorers in the late-seventeenth century prompted the Spanish to establish missions in far East Texas. In 1718 Don Martín de Alarcón was appointed the first Spanish governor of Texas. Along with Father Antonio de San Buenaventura y Olivares, Alarcón was sent to establish a mission, presidio, and villa on the San Antonio River (Habig 1977:20). Neither the site of the original Mission San Antonio de Valero "near the first spring, half a league from a high ground and adjoining a small thicket of live oaks" (Hoffmann 1938:318) nor the second "little fortification" destroyed by a hurricane in 1724 (de Paredes 1727) have been identified. Mission San Antonio de Valero (later to become known as the Alamo) was established in its third and present location in 1724 .

The Acequia del Alamo was established to supply water to Mission Valerio and to irrigate the surrounding agricultural lands. Emanating a short distance below the headwaters of the San Antonio River in present day Brackenridge Park, the canal ran approximately 3.5 miles before re-entering the river at the large bend just south of the mission. Later branches to the east and south of the Alamo acequia increased the total length of the canal to approximately 10 miles, bringing additional land, including the current project area, under irrigation (Figure 3).

These lands remained the property of Mission Valero until 1793 when the mission compound and surrounding irrigated lands were deeded to Spanish residents of the mission and to the Adaesaños, settlers from the community of Los Adaes forced to seek refuge in San Antonio when Spain withdrew from east Texas in 1774 (Figure 3). The current project area involves two of these suertes, or tracts of land, granted to Adaesaños Miguel Antonio (Tomás) Martinez and Ramon de los 


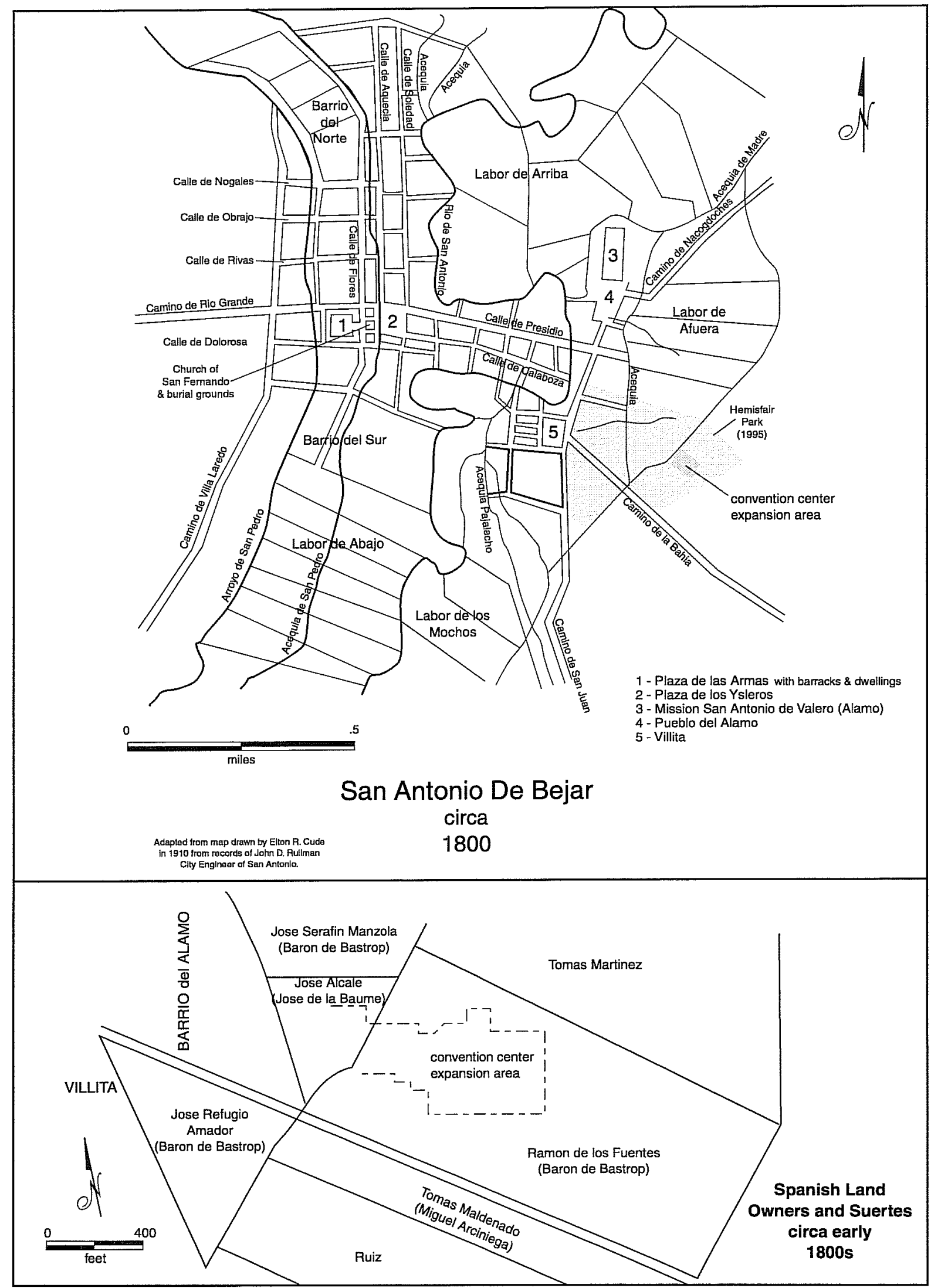

Figure 3 . Spanish land divisions and owners. 
Fuentes (Chabot 1937:216; City Engineer's Map 1916, copy on file at CAR).

In the decades that followed, San Antonio was involved in much of the political unrest between Mexico and Spain. In 1824, three years after Mexico became an independent nation, the new Federal Constitution of Mexico merged the provinces of Texas and Coahuila into one state with Saltillo as the capital. The following year, Texas became a separate department with San Antonio de Bexar as the capital. Twelve years later, San Antonio was the site of the famous Battle of the Alamo which paved the way for the 1836 Texan defeat of the Mexican army and the beginning of the Republic of Texas (see Johnson et al. 1997 for more detail).

Political unrest and military incursions by Mexican troops did not completely cease until Texas was annexed by the United States in 1844 . The ensuing influx of people from the southern United States and Europe prompted land speculators to purchase large tracts of land for division into smaller lots for development.

\section{Project Area}

From the establishment of the Mission San Antonio de Valero until the mid-nineteenth century, the New City Blocks (NCB) comprising the project area were primarily agricultural lands with no structures or improvements (Johnson et al. 1997). The southern portion of the sewer and water lines installed during this project run through portions of NCB 689, 693, and 696 (Figure 4), the property purchased and subdivided by developer Joseph Beck in 1848 (see Johnson et al. 1997). The northern portion of the new sewer line crosses portions of NCBs $686,687,873$, and 874 , land also originally acquired by the Barón de Bastrop in 1810 (Figure 4).

The land containing NCBs 687 and 874 was sold by the Bastrop heirs to Philip Dimmitt (Johnson et al. 1997). In 1868, the property was divided among the Dimmitt heirs with the portion in question going to Texas P. Dimmitt and Alonza Dimmitt (Bexar County Deed Records [BCDR], Bexar County Courthouse,
San Antonio, Texas, Volume U1:391). Alonza Dimmitt transferred her property to George W. Brackenridge on April 27, 1869, and he immediately sold the property to William B. Leigh (BCDR U2:496, 499). Texas Dimmitt sold her portion to H. B. Adams and E. D. L. Wickes, early developers in San Antonio (BCDR $\mathrm{U} 2: 598$ ). These blocks were divided into individual house lots and, by 1873 , homes had been constructed along the North Street frontage (Figure 5).

The portion of the project area containing NCB 686 and 873 was acquired from the Bastrop heirs by Angel C. Torres, who in 1866 sold Lots 1 and 2 of NCB 686 to Jonathan Seibel (BCDR T2:342). Torres sold Lots 3 and 4 to Charles Harvey in January of 1866 (BCDR T2:367). Lots 5-8 are a portion of the Dimmitt tract held by Alonza Dimmitt. She sold Lot 8 to George Halameida in March, 1868 (BCDR U2:540). Lots 5-7 were sold to George Brackenridge in 1869 (BCDR U2:496). Brackenridge sold Lot 5 to Peter Linnartz in June, 1869, and Lot 7 to Anton Moszygemba in October, 1869 (BCDR V1: 253, V2:153). These owners apparently constructed the single-family dwellings along Lafitte Street shown on Koch's 1873 Bird's Eye View of the City of San Antonio (Figure 5).

NCBs 687 and 874 were acquired by Urban Renewal in August 1970, and the title transferred to the city of San Antonio (BCDR 6407:1). NCB 686 and 873 were acquired by Urban Renewal in November 1966, and the title transferred to the city of San Antonio (BCDR 5685:644).

\section{Methodology}

A twofold approach was employed for the archaeological investigations of the SAWS sewer- and waterline installation based on differences in recent land-use history between the northern and southern sections of the project area (Figure 6). The route of the northern section of the sewer line extends $400 \mathrm{ft}$ from the corner of Market and Bowie streets on an east/southeast line parallel with Bowie Street. While the currently vacant block between Market and Bowie streets had been the site of commercial development during the first half of the twentieth century, this portion of the project area was outside the HemisFair boundaries and therefore not directly involved in the construction 


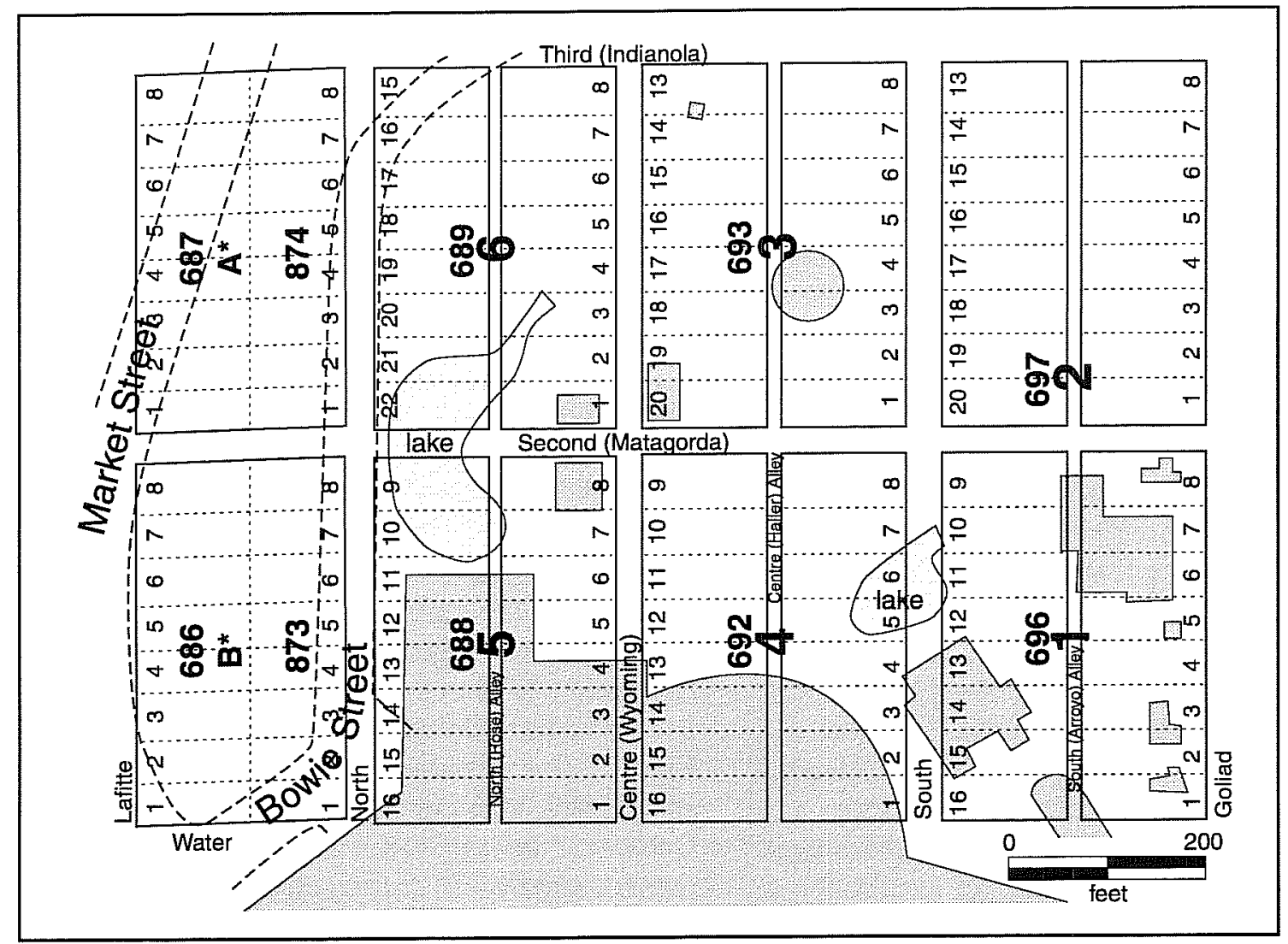

Figure 4. Lot and block designations for project area. Looking east.

Figure 5. Detail from Bird's Eye View of the City of San Antonio, drawn by Augustus Koch in 1873. Looking east.

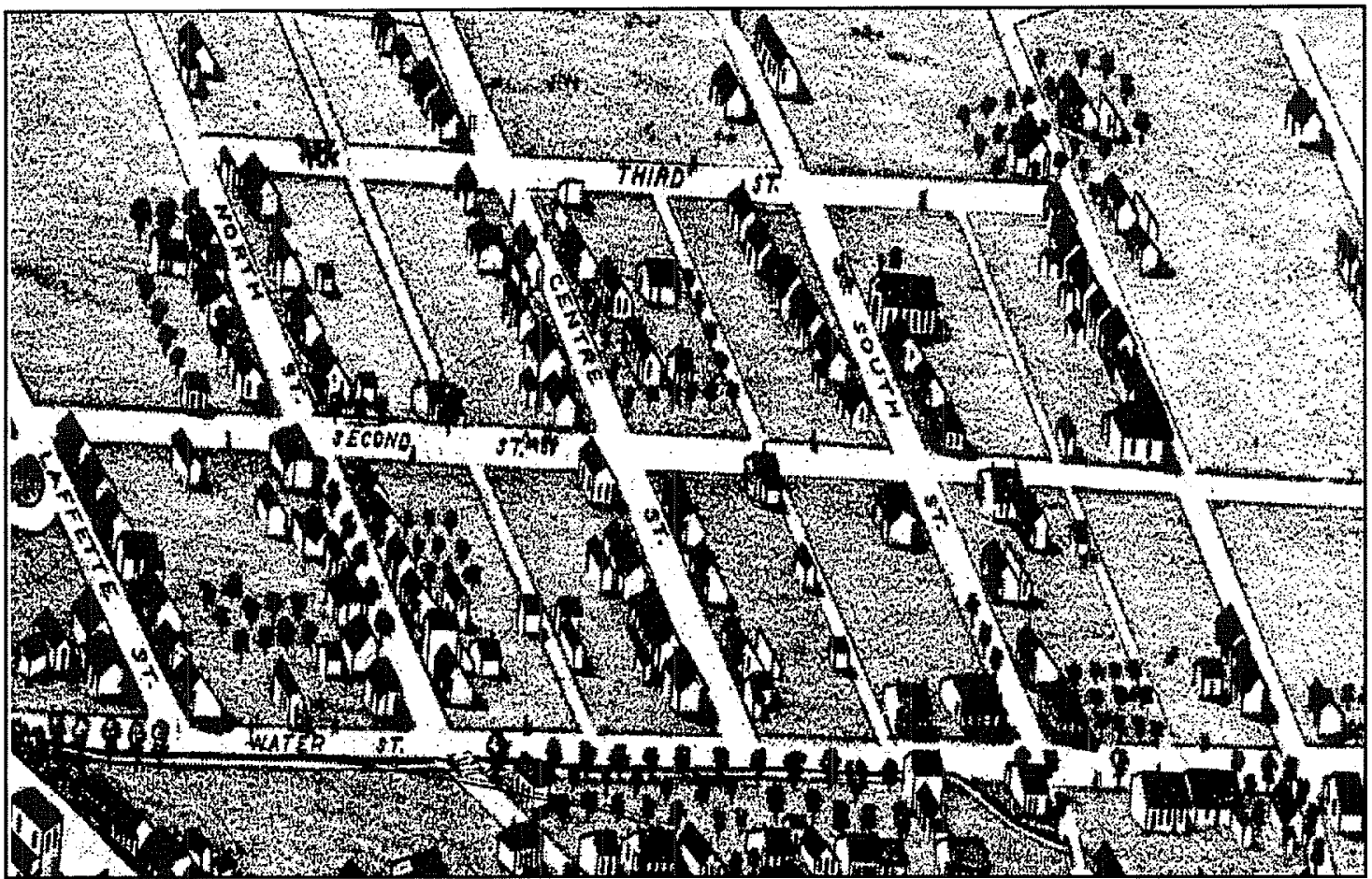




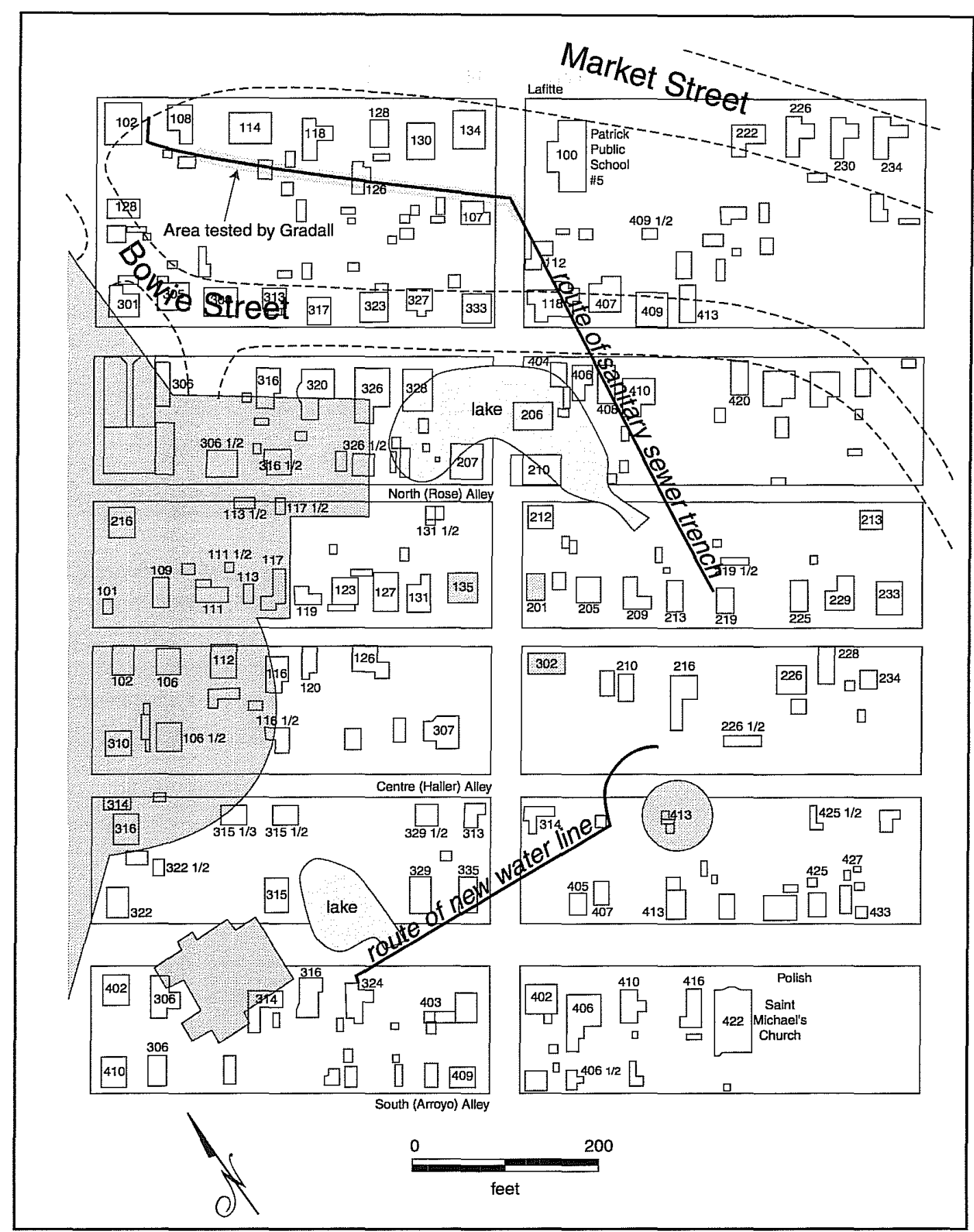

Figure 6. Route of SAWS sewer and water trenches showing area of historic and modern impact. Adapted from the 1896 Sanborn map.

associated with HemisFair Plaza. This land-use history suggested there was potential for preservation of intact historical remains from early homes on this block.

The southern portion of the sewer line extends $600 \mathrm{ft}$ from the north side of Bowie Street to the tie-in spot north of the Tower of the Americas. This section was designed to run under Bowie Street and continue through a section of HemisFair Park that had been heavily disturbed by construction of an artificial lake. The route of the $400 \mathrm{ft}$ of 8 -inch water line was also in an area previously disturbed during construction of 
the Tower of the Americas and a second artificial lake (Figure 6); therefore, excavations in the southern portion of the project area were periodically monitored.

The sewer trench, which varied from 12-15 ft in depth and was 9-10 ft wide, was excavated by a 9600 Kabota trackhoe with a $5-\mathrm{ft}^{3}$ bucket. The trench for the new water line that skirts the north side of the Tower of the Americas was $4 \mathrm{ft}$ deep and $3 \mathrm{ft}$ wide and was excavated by a backhoe with a 24 -inch bucket.

\section{Gradall Trenching}

One continuous Gradall trench was excavated prior to the actual utility trenching activities to search for historic features. This trench ran along the center-line of the northern portion of the proposed sewer-line route between Market and Bowie streets Excavation of the Gradall trench began at the concrete circle at the corner of Market and Bowie and continuing to a manhole $100 \mathrm{ft}$ north of Bowie Street (Figure 7). The trench was approximately $5.5 \mathrm{ft}$ wide and was excavated to a minimum depth of $3 \mathrm{ft}$ below the surface except when buried utilities were encountered. Because of Gradall mobility limitations, the trench was excavated in sections averaging $10 \mathrm{ft}$ in length. Soil was removed in 2-3 inch levels. The excavation of each section was monitored at all times by a two-person team. One person monitored the excavation for features while the other monitored the backdirt for artifacts. As a safety measure, open sections of the trench were backfilled at the end of each day. The actual excavation of the sewer trench in the Market/Bowie street island was also monitored periodically.

\section{Assessment and Recording Protocol}

Construction projects of the scale of the Convention Center Expansion require an immense amount of coordination between all the contractors involved and close adherence to scheduling and completion deadlines. Therefore, it was necessary to design a protocol that would allow for accurate and comprehensive

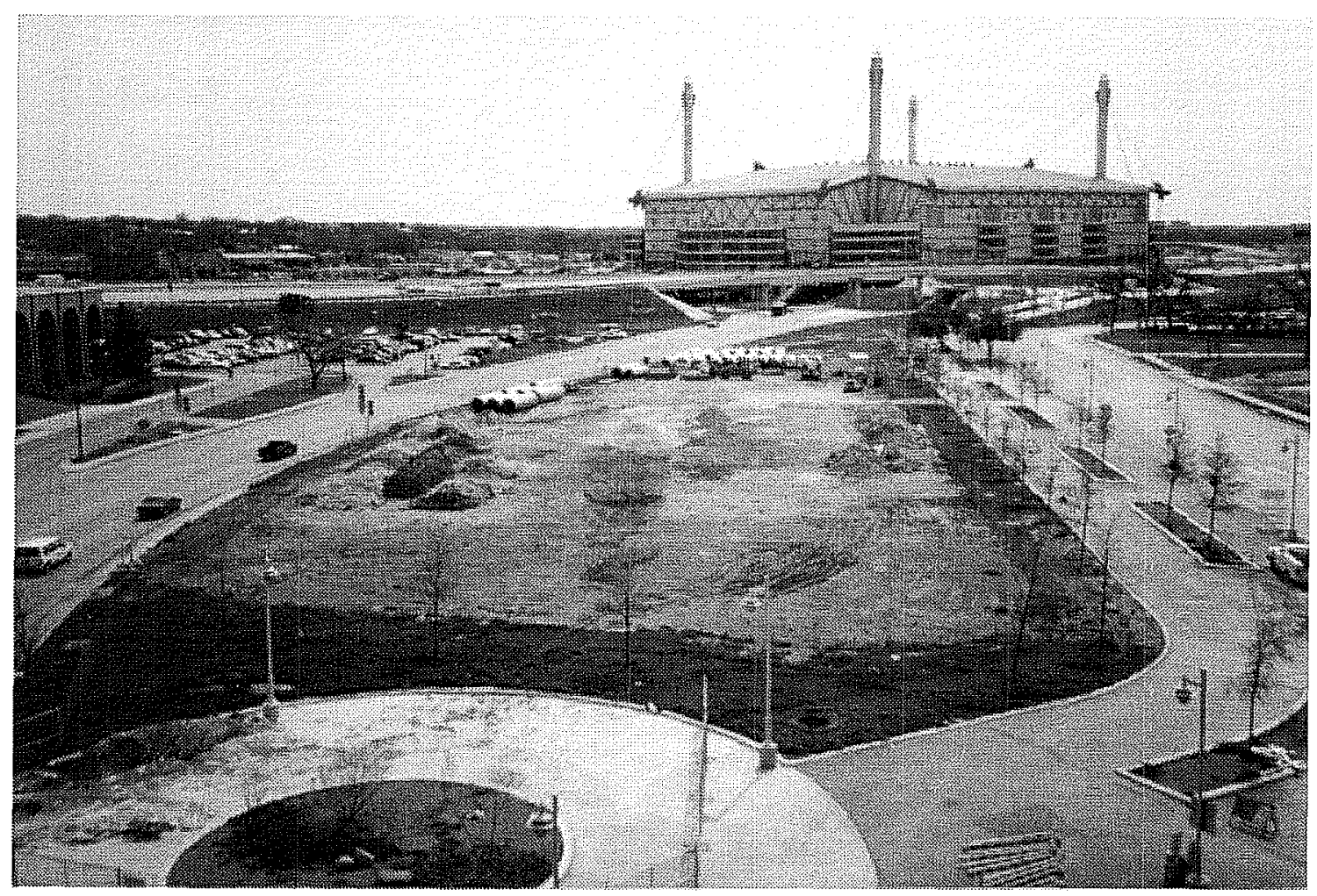

Figure 7. Area of Gradall investigations in undeveloped traffic island between Mark and Bowie streets. Looking east. 
assessment and recording of archaeological features and artifact concentrations while minimizing interference and delays to the project. Based on the THC's definition of significant archaeological deposits necessitating work stoppage for further investigation as any intact deposit predating 1850 or "unique or rare" deposits post-dating 1850 , parameters were established to assist in quickly differentiating deposits pre- and post-dating 1850 in the field. An enlargement made of the project area from Koch's 1873 Bird's Eye View of the City of San Antonio was used to identify structures and features existing at that time that might be encountered along the proposed sewer route (Figure 5). The current project-area configuration was overlaid on the 1896 Sanborn Map of the area for orientation and identification of later structures (Figure 4). Previously identified ceramic maker's marks (Tennis 1997), a list of local druggists (Appendix A), and/or the presence of artifact types and construction materials listed in Table 1 were used to assign features and associated artifact concentrations to the post- 1850 period.

Portions of historic features exposed during trenching activities were photographed, measured, and plotted on a scaled field map. Deposits in the immediate area were examined for diagnostic artifacts which, if present, were collected and used to assess the age of the feature or, in the case of privies, wells, or cisterns, the approximate time period of the fill episodes.

\section{Results}

No historic features or artifact concentrations were encountered during excavations in the southern section of the project area. Inspection of the sewer-line trench revealed that all the original black-clay layer that would have contained historic deposits had been removed prior to or during construction of Bowie Street and the artificial HemisFair lake. Excavation of the water-line trench revealed that 24-36 inches of undisturbed black clay remained in some areas of the park. However, no artifacts or features were encountered.

In the northern section of the project area, an 18-24inch-thick layer of undisturbed black clay was present beneath 24 inches of stabilized base and caliche fill. During Gradall operations, numerous $2-3$ inch utility lines were found intruding into this layer, but with the exception of remnants of a ca. 1950 concrete parking garage, no historic features or artifacts were revealed.

The actual trench for the sewer line was $10 \mathrm{ft}$ wide to accommodate the 60 -inch pipe, thus extending an additional two feet on either side of the area previously inspected during the Gradall operations. Three historic rock-lined features were exposed in the wider trench in the northern section (Figure 6). These features are believed to be privies or cisterns associated with the residences at 118,114 , and 108 Lafitte which are each

Table 1. Post-1850 Materials

\begin{tabular}{|l|l|}
\hline \multicolumn{1}{|c|}{ Post-1850 materials } & \multicolumn{1}{c|}{ Reference } \\
\hline Wire nails & Fontana (1965) \\
\hline Yellow brick & Steinbomer (1983) \\
\hline Ironstone & Miller (1991) \\
\hline Albany, Bristol-glazed stoneware & Greer (1981) \\
\hline Decal decorated whiteware & Durrenberger (1965) \\
\hline Band \& Line decorated whiteware & Miller (1991) \\
\hline
\end{tabular}




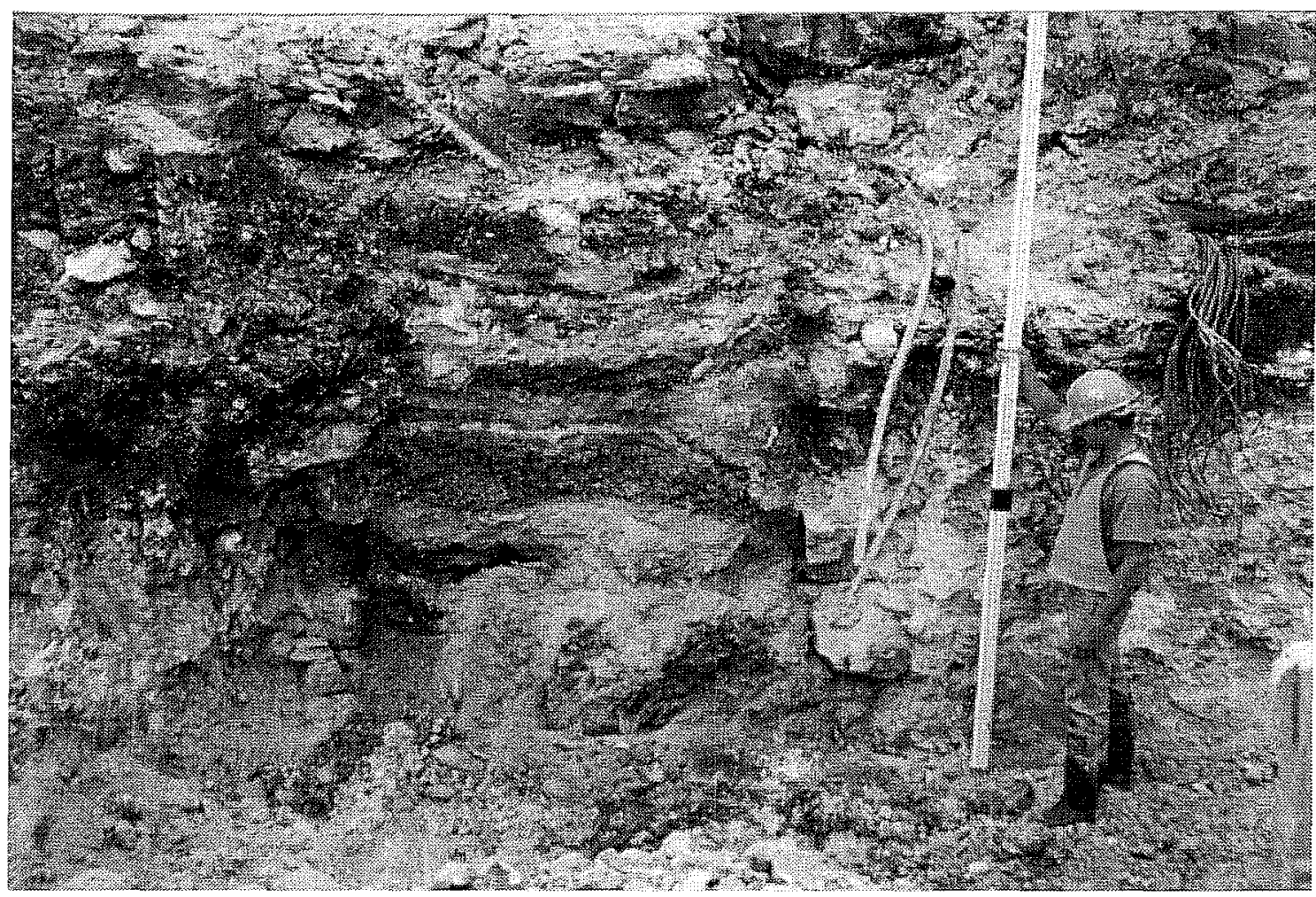

Figure 8. Feature 1 immediately after exposure. Looking south. Note the layered evidence of depositional events.

Figure 9. Feature 1 following partial cave-in and subsequent investigation. Looking south.

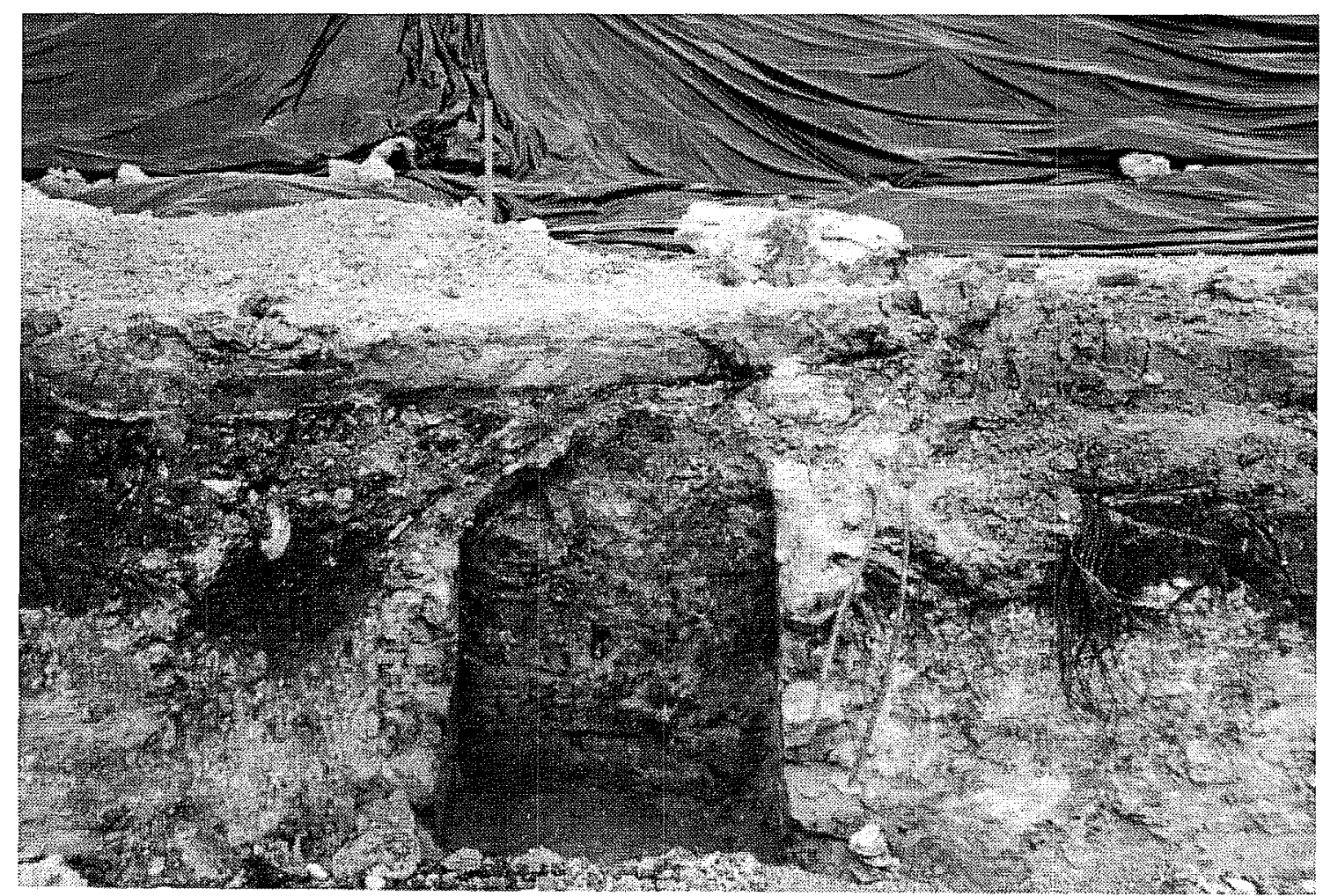


present on Koch's 1873 Bird's Eye View of the City of San Antonio. While the choice of stone as a building material suggests a mid-nineteenth century construction date for these features, associated diagnostic artifacts (described below) consistently dated between 1890-1910, the time period when privies became trash receptacles as people in the area began to use the city sewer service (Brown and DeLaO 1997).

\section{Feature 1 (Figures 8 and 9)}

Feature 1 is located $90 \mathrm{ft}$ south of Market Street and $200 \mathrm{ft}$ east of the Bowie-Market street intersection. This area represents the back of Lot 5, NCB 686 which was purchased by Peter Linnartz in June 1869 (BCDR V1: 253), and is associated with the residence formerly at 118 Lafitte (Figure 6).

The east and west walls of Feature 1 were exposed in the south profile of the trench. They begin 24 inches below the surface and extend to a depth 114 inches below the surface. The walls are 16 inches thick and made of uncut limestone blocks which range in length from 4-12 inches. Feature 1 measures 92 inches across with an interior width of 60 inches. The feature fill is composed of loosely packed clay loam mixed with differing amounts of ash, which form distinct layers indicative of multiple depositional and burning events.

Heavy rains overnight caused a large portion of the privy fill to collapse, providing an opportunity to further examine the feature interior without delaying the construction schedule. As seen in Figure 9, the privy vault is square and the southern wall of the privy re- mains intact. Diagnostic artifacts collected from Feature 1 are listed in Table 2.

\section{Feature 2 (Figure 10)}

Feature 2 is located $150 \mathrm{ft}$ east of the Bowie-Market street intersection and $80 \mathrm{ft}$ south of Market Street. This area represents the back of Lot 4, NCB 686, purchased by Charles Harvey in January 1866 (BCDR $\mathrm{T} 2: 367$ ), and is associated with the residence formerly at 114 Lafitte (Figure 6).

The east and west walls of Feature 2 were exposed in the south profile of the trench. The rock walls begin 36 inches below the surface and extend to a depth of 78 inches below the surface. The deposit, however, continues to 96 inches below the surface.

The walls are 16-18 inches thick and are made of uncut limestone blocks ranging in length from 4-12 inches. Feature 2 measures 114 inches across with an interior width of 82 inches. Diagnostic artifacts collected from Feature 2 are listed in Table 3.

\section{Feature 3 (Figure 11)}

Feature 3 is located $30 \mathrm{ft}$ east of the Bowie-Market street intersection and $60 \mathrm{ft}$ south of Market Street. This area represents the back of Lot 2, NCB 686, purchased by Jonathan Seibel in 1866 (BCDR T2:342), and is associated with the residence formerly at 108 Lafitte (Figure 6).

Table 2. Diagnostic Artifacts from Feature 1

\begin{tabular}{|l|l|l|l|}
\hline \multicolumn{1}{|c|}{ Artifact Type } & \multicolumn{1}{c|}{ Markings } & \multicolumn{1}{c|}{ Date } & \multicolumn{1}{c|}{ Reference } \\
\hline 31/2" paneled pharmacy & $\begin{array}{l}\text { B. E. Voelcker's Drug Store } \\
\text { New Braunfels, Texas }\end{array}$ & post 1898 & City Directory \\
\hline 4" whiteware saucer & Pearl White - Goodwin Bros. & $1885-1897$ & Gates and Ormerod (1982:52) \\
\hline bottle base, 4" diam. & Pat Nov. 2, 1868 & post 1868 & \\
\hline 12" whiteware platter & Cartwright Bros. & $1887-1896$ & Gates and Ormerod (1982:31) \\
\hline chamber pot & GM \& Son, Liverpool & $1884-1891$ & Gates and Ormerod (1982:200) \\
\hline
\end{tabular}






Figure 10. Feature 2. Looking south.

Figure 11. Feature 3. Looking west.

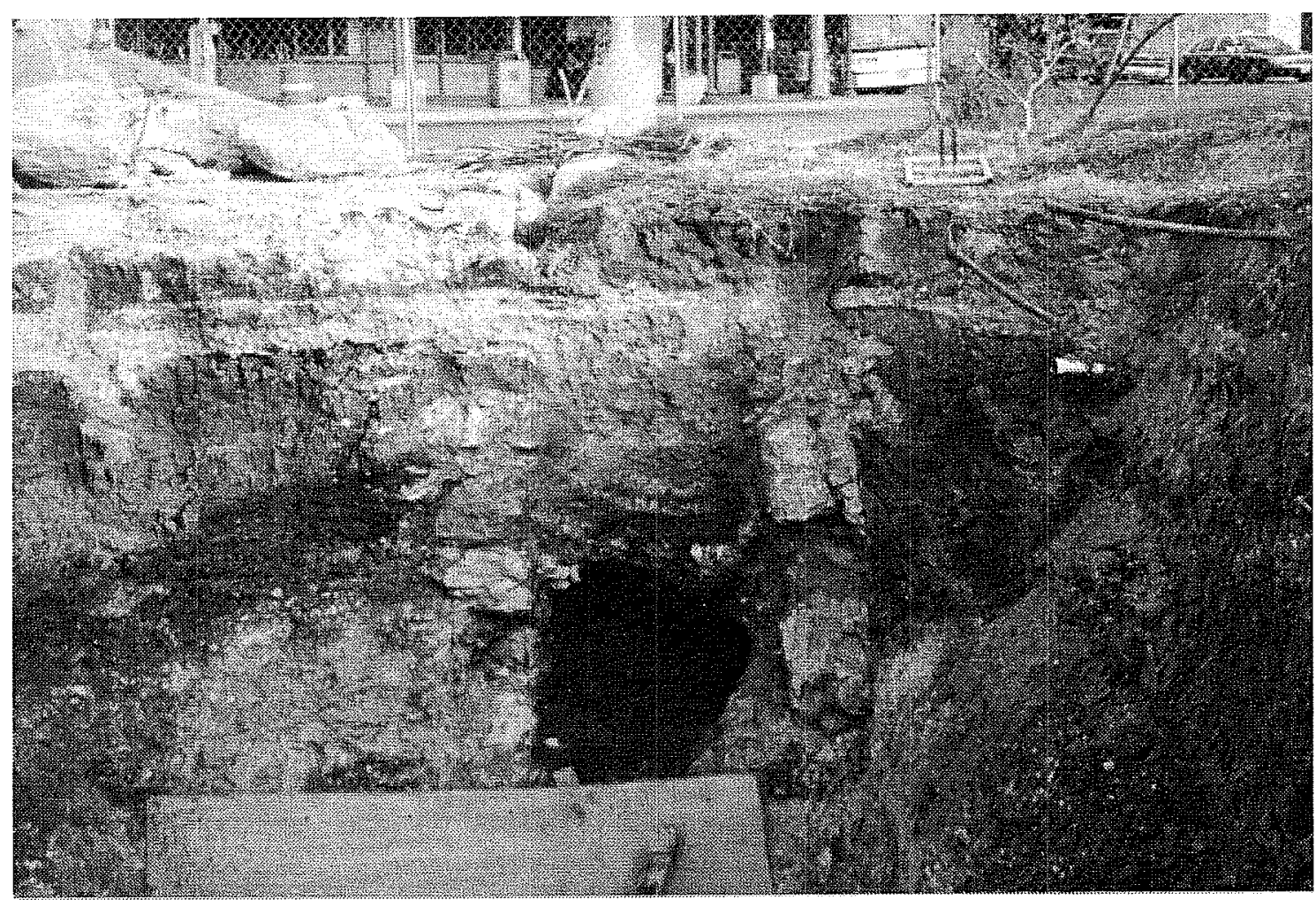


Table 3. Diagnostic Artifacts from Feature 2

\begin{tabular}{|l|l|l|l|}
\hline \multicolumn{1}{|c|}{ Artifact Type } & \multicolumn{1}{|c|}{ Markings } & \multicolumn{1}{c|}{ Date } & \multicolumn{1}{c|}{ Reference } \\
\hline Stoneware & Bristol \& Albany slip & post 1884 & Greer (1981) \\
\hline Porcelain & $\begin{array}{l}\text { decal decorated } \\
\text { green leaf design }\end{array}$ & post 1850 & Durrenberger (1965) \\
\hline
\end{tabular}

The north and south walls of Feature 3 were exposed in the west face of the trench. The stone walls begin approximately 24 inches below the surface, but due to the location of this feature in the trench and the depth of the trench, complete measurements could not be obtained. Diagnostic artifacts collected from the back dirt of Feature 3 are listed in Table 4.

\section{Conclusion}

As expected, no historic features or artifact concentrations were encountered during excavations in the southern section of the project area. Inspection of the sewer-line trench revealed that all the original blackclay layer that would have contained historic deposits had been removed prior to or during construction of Bowie Street and the artificial HemisFair lake. Excavation of the water-line trench revealed that 24-36 inches of undisturbed black clay remained in some areas of the park. However, no artifacts or features were encountered.
In the northern section of the project area, a 18-24inch-thick layer of undisturbed black clay was present beneath 24 inches of stabilized base and caliche fill. Although no historic features or artifacts were revealed during Gradall operations, three historic rock-lined features were exposed and documented in the widened trench during utility installations. These features are believed to be privies or cisterns associated with residences at 118, 114, and 108 Lafitte Street. Diagnostic artifacts associated with these features consistently dated between 1890-1910, the time period when people in the area began to use the city sewer service (Brown and DeLaO 1997). No pre-1850 deposits were impacted by this utility installation project.

Table 4. Diagnostic Artifacts from Feature 3

\begin{tabular}{|l|l|c|c|}
\hline \multicolumn{1}{|c|}{ Artifact Type } & \multicolumn{1}{|c|}{ Markings } & Date & Reference \\
\hline 5" paneled pharmacy & $\begin{array}{l}\text { W. D'Albini, San Antonio } \\
\text { (Pat. May 24,88 W. T. Co.) } \\
\text { on bottom }\end{array}$ & post 1888 & \\
\hline 6" undec whiteware saucer & Clementson Bros. England & $1867-1880$ & Godden (1964:149) \\
\hline wire nail & & post 1879 & Fontana (1965) \\
\hline
\end{tabular}




\section{References Cited}

ATC Associates

1996 Geotechnical Exploration: Henry B. Gonzalez Convention Center Expansion, HemisFair Park, San Antonio, Texas. Report No. 50-07-96-00009, Volume IG. Manuscript on file. Center for Archaeological Research, The University of Texas at San Antonio.

Brown, M., and N. DeLaO

1997 Beneath the Crescent Moon: A Contextual and Architectural Analysis of Privies from the Alamodome Area. In Archaeology at the Alamodome: Investigations of a San Antonio Neighborhood in Transition, Volume III: Artifacts and Special Studies, edited by A. A. Fox, M. Renner, and R. J. Hard, pp. 256-272. Archaeological Survey Report, No. 238. Center for Archaeological Research, The University of Texas at San Antonio.

Bousman, C. B., A. A. Fox, K. J. Gross, and I. W. Cox

1995 Historical Archaeology in Downtown San Antonio, Texas: An Evaluation of Properties at the Proposed VIA Downtown Park and Ride Facility. Archaeological Survey Report, No. 240. Center for Archaeological Research, The University of Texas at San Antonio.

Campbell, T. N., and T. J. Campbell

1985 Indian Groups Associated with Spanish Missions of the San Antonio Missions National Historical Park. Special Report, No. 16. Center for Archaeological Research, The University of Texas at San Antonio.

Chabot, F. C.

1937 With the Makers of San Antonio. Artes Graficas, San Antonio.

Cox, I. W., and A. A. Fox

1983 Literature and Archival Study for the Development of HemisFair Park, San Antonio, Texas. Manuscript on file. Center for Archaeological Research, The University of Texas at San Antonio.

de Paredes, M. S.

1727 Vista de las Misiones del Rio Grande del Norte pr Fr. Miguel Sevillano de Paredes en 15 de Octobre. Archivo General de Mexico: Historia, Volume 29. Barker History Center, The University of Texas at Austin.

Durrenberger, E. P.

1965 Anderson's Mill (41TV130): A Historical Site in Travis County, Texas. Bulletin of the Texas Archeological Society 36:1-70.

Fontana, B. L.

1965 The Tail of the Nail: On the Ethnological Interpretation of Artifacts. The Florida Anthropologist XVIII(3) 2:85-92. 
Fox, A. A., M. Renner, and R. J. Hard (editors)

1997 Archaeology at the Alamodome: Investigations of a San Antonio Neighborhood in Transition, Volume I: Historical, Architectural, and Oral History. Archaeological Survey Report, No. 236. Center for Archaeological Research, The University of Texas at San Antonio.

Gates, W. C., Jr., and D. E. Ormerod

1982 The East Liverpool Pottery District: Identification of Manufactures and Marks. Historical Archaeology 16:1-358.

Godden, G. A.

1964 Encyclopedia of British Pottery and Porcelain Marks. Bonanza, New York.

Greer, G. H.

1981 American Stonewares, The Art and Craft of Utilitarian Potters. Schiffer, Exton, Pennsylvania.

Habig, M. A.

1977 The Alamo Mission, San Antonio de Valero 1718-1793. Franciscan Herald, Chicago.

Hester, T. R.

1978 Early Human Occupations in South Central and Southwestern Texas: Preliminary Papers on the Baker Cave and St. Mary's Hall Sites. Non-serial Publication 2. Center for Archaeological Research, The University of Texas at San Antonio.

Hoffmann, F. L. (translator)

1938 The Mesquía Diary of the Alarcón Expedition into Texas, 1718. Southwestern Historical Quarterly XLI:312-323.

Johnson, E. D., and I. W. Cox

1995 An Archival and Archaeological Study for the Relocation of Three Historic Homes in HemisFair Park, San Antonio, Texas. Archaeological Survey Report, No. 241. Center for Archaeological Research, The University of Texas at San Antonio.

Johnson, E. D., I. W. Cox, and C. B. Bousman

1997 HemisFair Park, San Antonio, Texas: An Archival Study for the Convention Center Expansion. Archaeological Survey Report, No. 249. Center for Archaeological Research, The University of Texas at San Antonio.

Lukowski, P. D.

1988 Archaeological Investigations at 41BX1, Bexar County, Texas. Archaeological Survey Report. No. 135. Center for Archaeological Research, The University of Texas at San Antonio.

Miller, G. L.

1991 A Revised Set of CC Index Values for Classification and Economic Scaling of English Ceramics from 1787 to 1880. Historical Archeaology 25(1):1-25. 
Steinbomer, R. A.

1983 Brickmaking in Texas. Texas Historical Commission Special Report (Rough Draft), Appendix: South Texas. Austin.

Taylor, F. B., R. B. Hailey, and D. L. Richmond

1991 Soil Survey of Bexar County, Texas. Soil Conservation Service, U.S. Department of Agriculture, Washington, D.C.

Tennis, C. L.

1994 Evaluation of Archaeological Material from the Little Church of La Villita Property, San Antonio, Texas. Archaeological Survey Report, No. 228. Center for Archaeological Research, The University of Texas at San Antonio.

1997 Ceramic Patterns and Variations. In Archaeology at the Alamodome: Investigations of a San Antonio Neighborhood in Transition, Volume III: Artifacts and Special Studies, edited by A. A. Fox, M. Renner, and R. J. Hard, pp. 1-37. Archaeological Survey Report, No. 238. Center for Archaeological Research, The University of Texas at San Antonio. 
Appendix A. List of Local Druggists

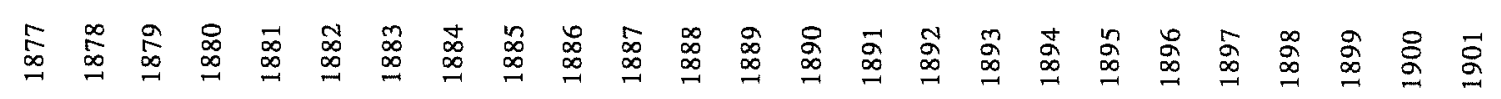

Calvin, James

Calvin, Wm. R.

Calvin, James

Dreiss, Adolph

Huppertz, Herman J.

Kalteyer, Frederic

Kalteyer, F. and Son

Kalteyer and Schuchard

Kalteyer, W. C.

$\mapsto$

Nette, August, Sr.

Nette, August, Jr.

Nette and Son

Schasse, Conrad

Scheff, Wm.

Elbe, C. B

Dowling and Flood

Orynski, L.

Orynski and Bro

Orynski and Co.

Elbers and Landy

Battelle Bros.

Cohn, R. and Co.

Elliot and Ragland

Hervey and MacDonald

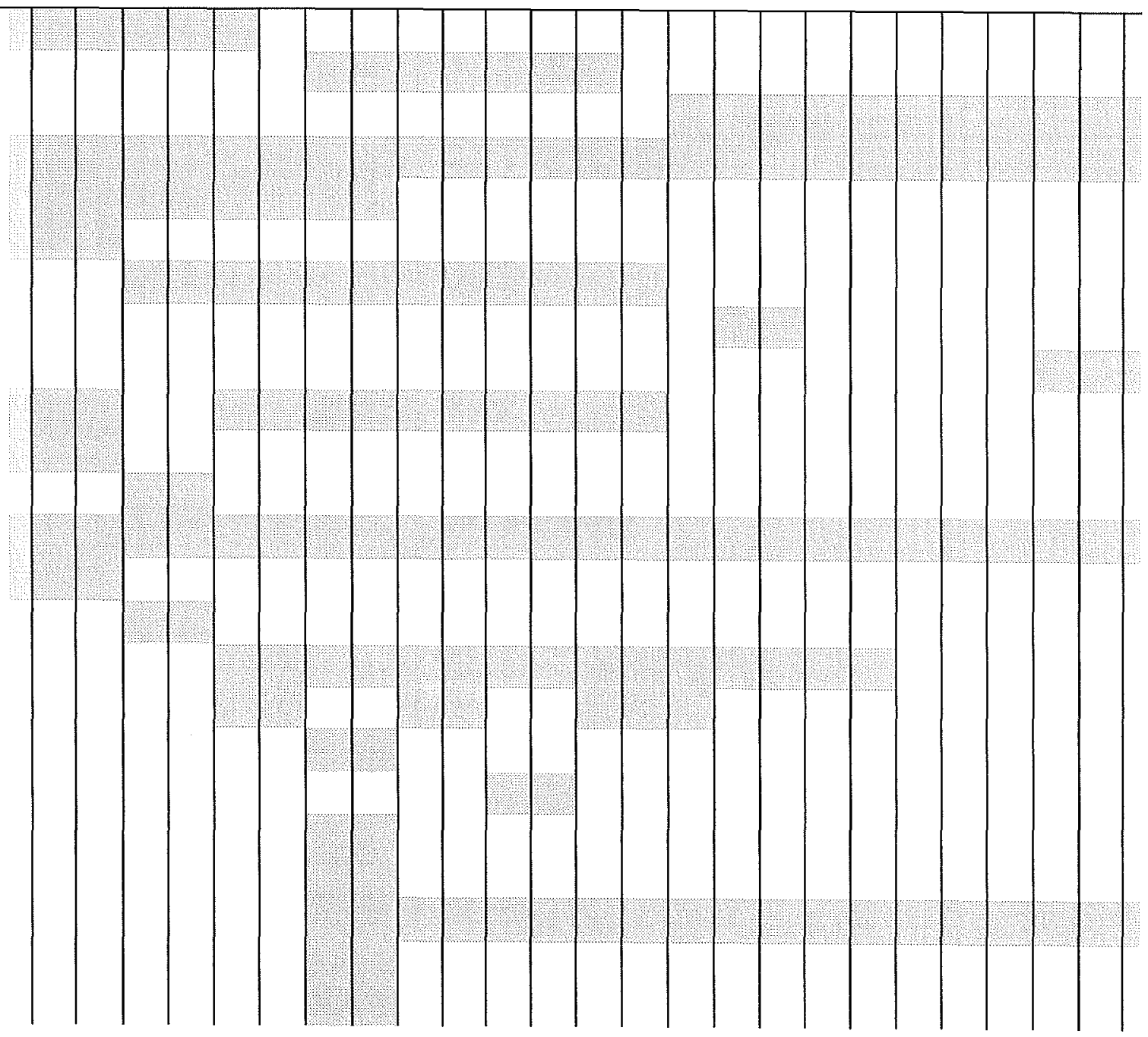


Appendix A. continued

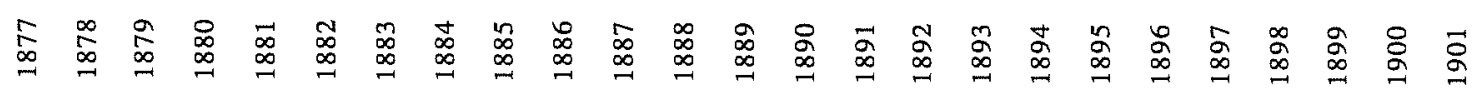

Wetzstein, E. B.

Wetzstein, Mrs. E. B.

Raglan and Co. (City Drug Store)

Raglan and Schachner (City Drug Store)

City Drug Store

Rice Bros.

Blair, Henry, A.

Landry, J. Omar

Bodemann, J. U.

D'Albini, Wm.

D'Albini, Wm. and Co.

Devine, James D.

Jones, Joseph $\mathrm{H}$.

Lockert, R. H.

Wheatley Bros.

Ernest, I. W. (India Drug)

Schuchard, $\mathrm{H}$.

Spellessy, C.

Spellessy, Thomas J.

Voelcker, R. F. (Central)

Yarbrough and Son

Yarbrough and Giles

Aransas Pass Drug Store

Colwell, F. C.

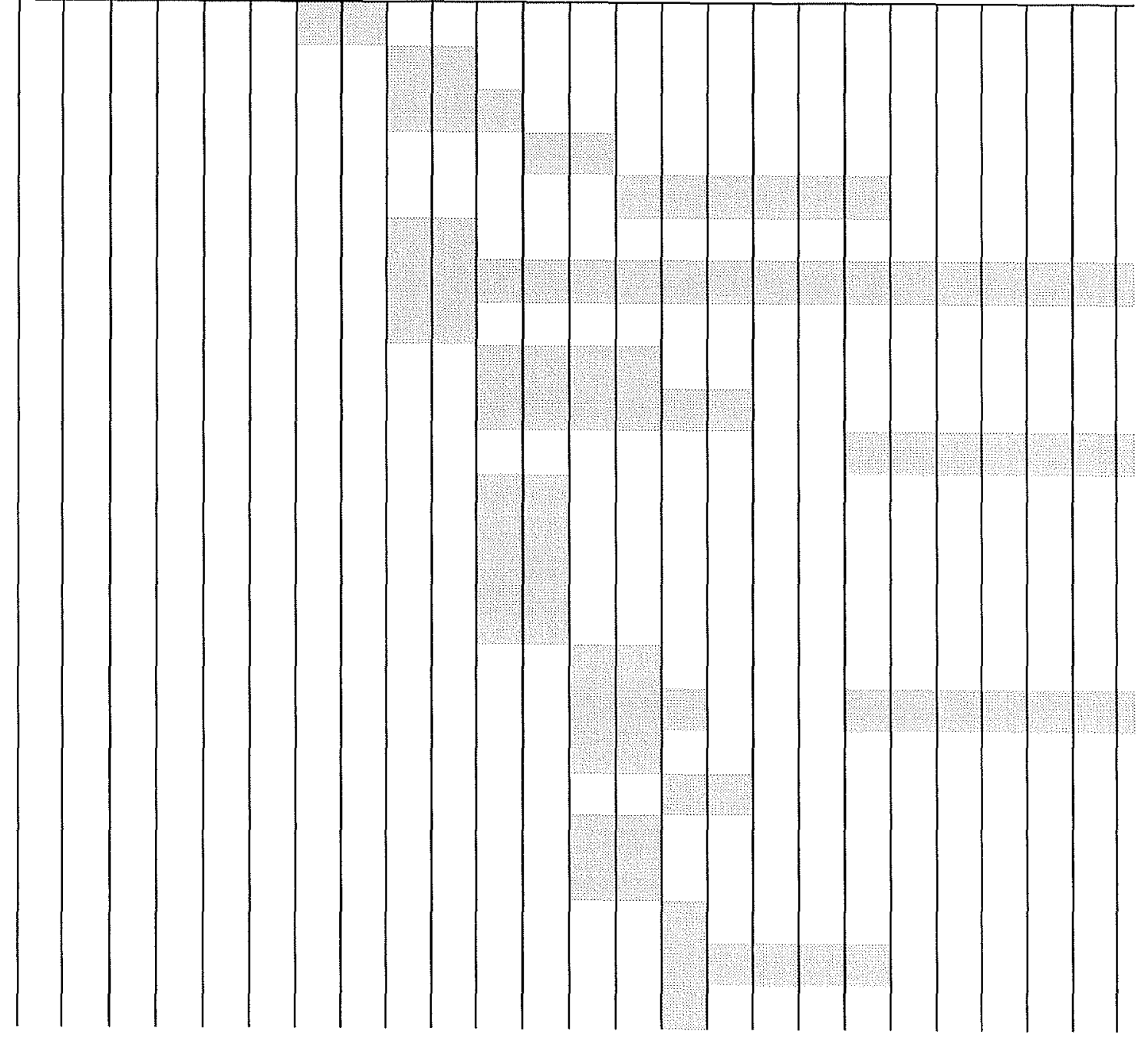


Appendix A. continued

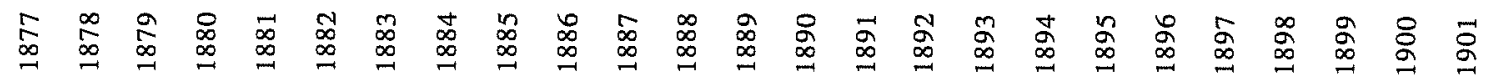

Cunningham's Drug Store

Downey, J. W.

Duncan, T. B.

Farmer Drug Store

Hogue, Elton

Martinez, $\mathrm{H}$.

McLordom and Wilson

Miller, Henry W.

Miller, Mrs. Henry W.

Mission Drug Store

San Pedro Drug Store

San Pedro Pharmacy

Schweppe, August

Stein, P. S.

Sunset Drug Store

Tip and Silverthorn

Appmann, Wm.

Campbell, Carl

Crescent Pharmacy

Harrison, J. T.

Jungkind, E.

Jungkind and Fischer

Koch, J. G.

Lee, L. R.

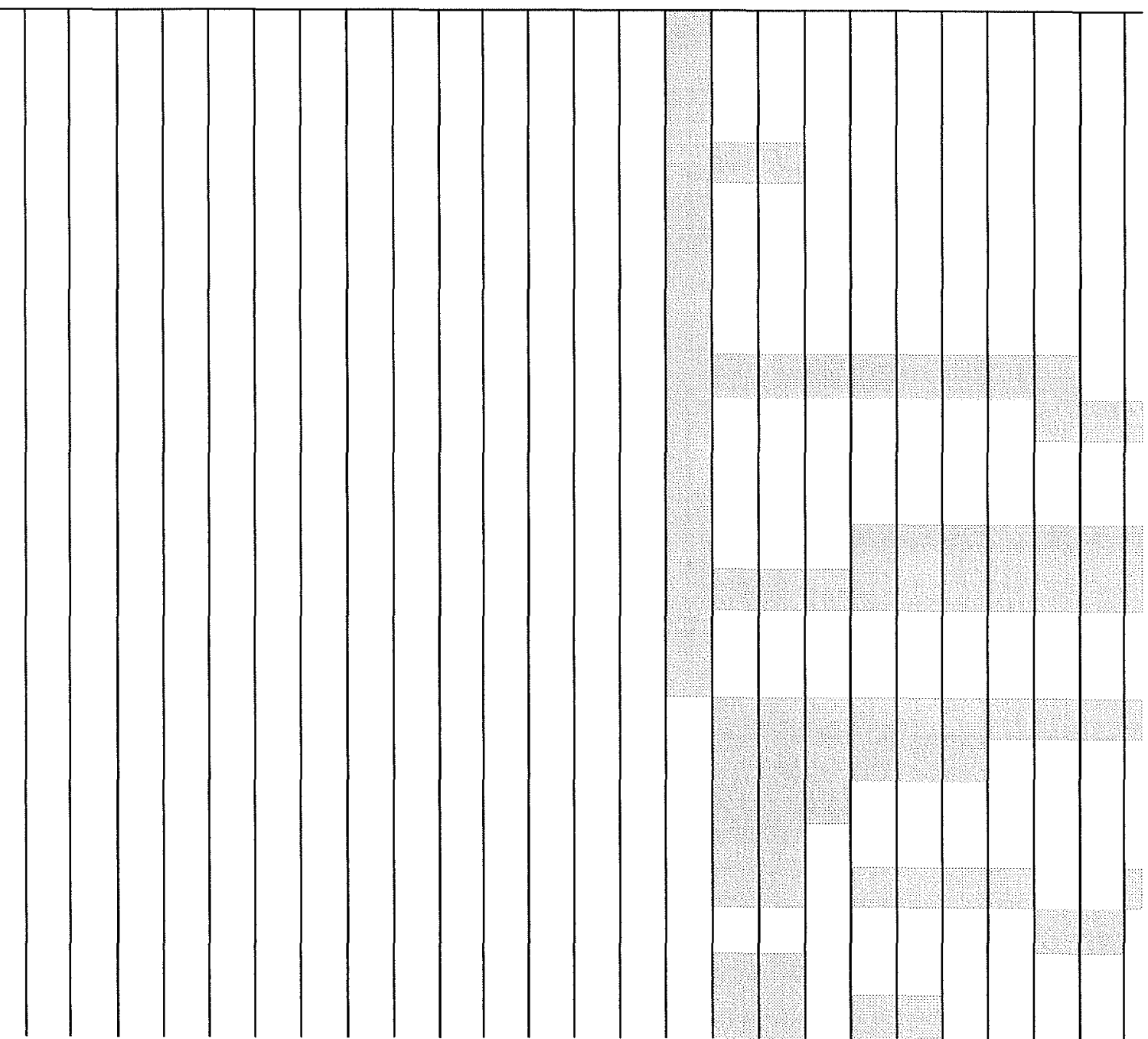


Appendix A. continued

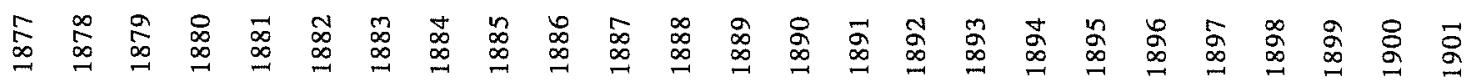

Meissners West End

Post Office Drug Store

Reuss, E. W.

San Antonio Drug Co. (wholesale)

Sar ro, Joseph

Smith, Mrs. R. B.

Spahn, Louis

Willey, John A.

Booker, E. M.

Bristow, B. W.

Central Drug Store

Duncan, T. B. (Central Drug)

Diaz, F. A. and Co.

James, W. F.

Jones and Virden

Silver thorn and Wayne

Silverthor $n$ and Wagner

Wlash, J. M.

Young, N. C.

Belcia, C. E.

Petty, J. M.

Pfeiffer, $J$.

Tallaferro, J. W.

Chappa and Dreiss

Eagle Pharmacy

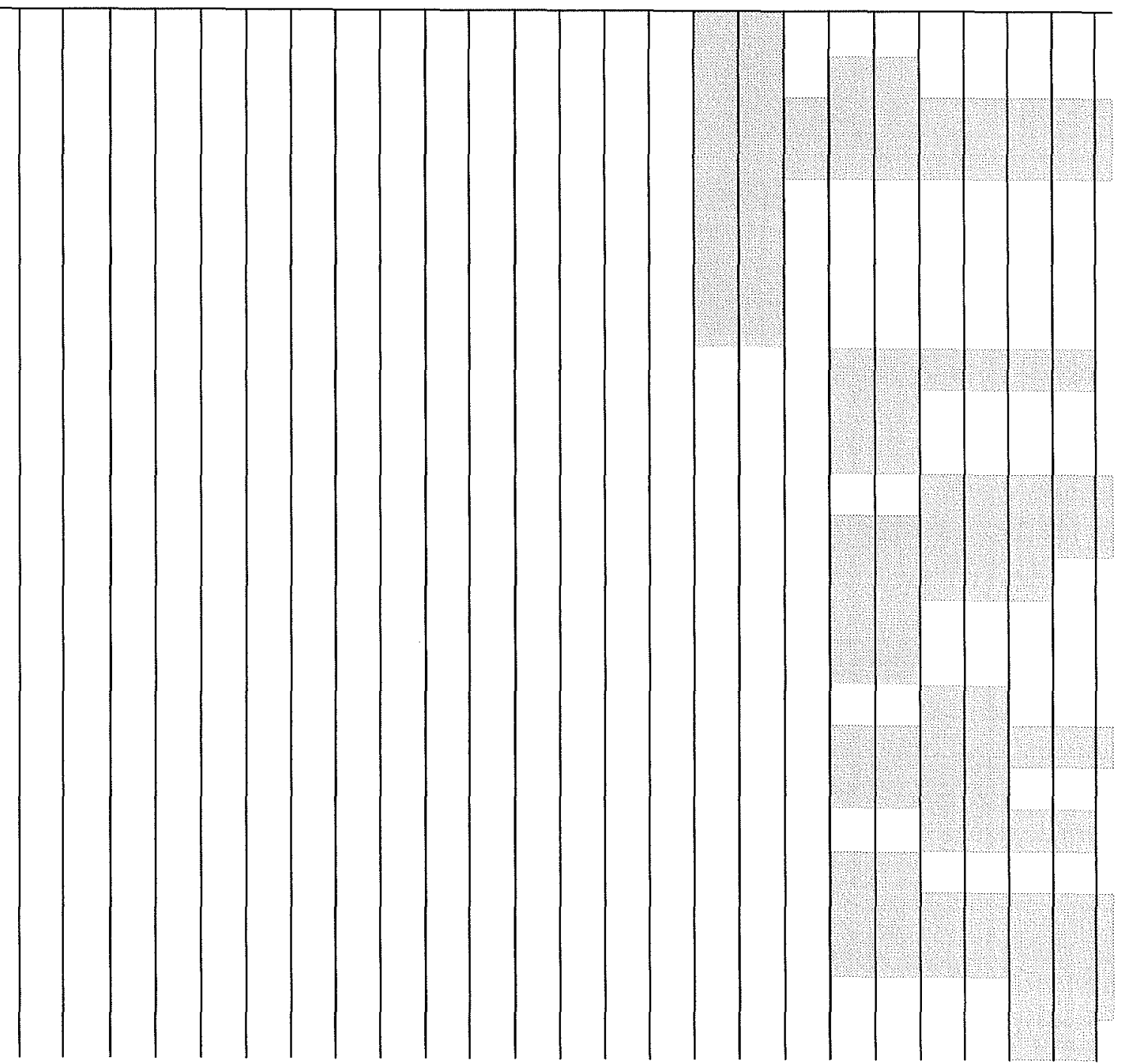


Appendix A. continued

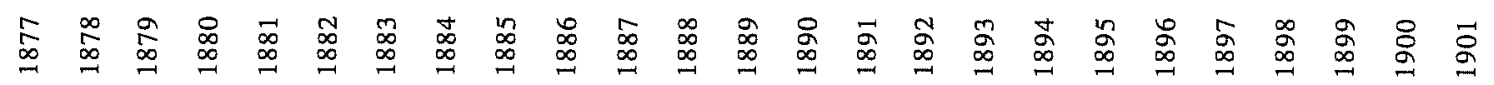

International Drug Store

Milam Square Drug Store

Milburn and Alexander

Milburn Bros.

Miller, Fannie

Patrick Bros.

Burke, J. A.

Canaman, I.

Fischer and Davis

$\stackrel{N}{N}$

Houck, F. A.

Rewand, J. R.

Swearingen Drug Co.

\begin{tabular}{|l|l|l|l|l|l|l|l|l|l|l|l|l|}
\hline &
\end{tabular}


